\title{
NALLD NOTE
}

\section{JOINT NATIONAL COMMITTEE for LANGUAGES (JNCL)}

ATTENTION! For those who are planning workshops or conferences for the next year, consider contacting the JNCL Office. J. David Edwards, Liason Director of the Office, has developed a workshop entitled Influence, Effectivness and Language Policy: A Political Action Workshop. Groups interested in arranging such a workshop should contact the JNCL Office, Suite 210, 11 Dupont Circle, NW, Washington, D.C. 20036. (202) 483-7200. Sponsors must be prepared to cover the expenses for the workshop leaders.

\section{SUMMER INSTITUTES}

The University of Northern lowa is planning its fifteenth annual Summer Institute in France for teachers of French. The dates are June 19 to August 8, 1982 in Angers and Bretagne and June 19 to July 24, 1982 in Anger. His program is designed for those who need intensive training in spoken French, and who do not wish to see France as tourists but rather live with French families in a French community. Enrollment is limited. Six to eight credit hours are offered. For information contact Mr. Andre Walther, Director, 1982 French Summer Institute, University of Northern lowa, Cedar Falls, IA 50614.

The University of Montreal continues to offer intensive and immersion programs in French and Quebec Culture and Civilization for non-French speaking students. For information contact the Ecole de francais, University of Montreal, 3333 Queen Mary \# 528, Montreal, Quebec H3V 1 A2. (514) 343-7386.

\section{ANNUAL BUSINESS MEETING}

The final business meeting of NALLD and the first annual business meeting of IALL, the International Association for Learning Laboratories was held on Saturday, November 27, 1981 in Denver. The change in the name of our organization and the new constitution were both approved by the members and the announcement was made at the meeting. Joseph Sheehan, the last president of NALLD presided at the meeting and then handed the Chair to Victor Aulestia, the new president of IALL. The names of other officers were also announced:

The President-Elect is Roger A. Sanches-Berroa, Director of the Language Laboratory at Wesleyan University, Middletown, CT. The Secretarv is Mary Lynne Flowers, Director, 
Language Laboratory, University of Kentucky. The Treasurer is Leslie F. Bailey, Director, Language Laboratories, Northwestern University, Evanston, IL.

\section{NEW EXECUTIVE DIRECTOR}

Sam Burggraaf has submitted his resignation as Executive Director of IALL. Mr. Burggraaf has accepted the position of Vice-President of Tandberg of America. Those of us who have worked with Sam during the last five years know how much he has contributed to NALLD. He was one of the prime movers in planning the FLEAT conference and he has played a very positive role during his tenure in the office of executive secretary. After regretfully accepting Mr. Burggraaf's resignation, Victor Aulestia, President of IALL announced the appointment of C. P. Richardson, Director of Language Laboratories at Ohio University, Athens, $\mathrm{OH}$ as the new Executive Director. Mr. Richardson is the former editor of the NALLD Joumal and served as director of the NALLD Publications Center.

\section{NALLD Participation at the AECT Convention}

Association for Educational Communications \& Technology (AECT)

The 1982 annual convention will be held in Dallas from May 2 through May 6. NALLD participation is as follows:

Monday May 3, 1982. 1 P.M. to 4:15 P.M.

"Planning and remodeling Language Laboratories" Presentors will be Victor Aulestia, University of Maryland-Baltimore County, Jackie Tanner, Georgetown University, and Charles Richardson, Ohio University.

Tuesday May 4, 1982. 10:30 A.M. to 11:45 A.M.

"Teaching Instructional Materials Preparation Through Self-Directed Programmed Instruction." Presentor will be Dr. C. Y. Oh, University of Alberta.

Tuesday May 4, 1982. 1:30 P.M. to 4:15 P.M.

"Half-a-Conversation on Videodisc: Foreign/Second Language Learning with new Technology" Presentors will be Dr. Edward Schneider and Junius Bennion, Brigham Young University. The second afternoon presentation will be entitled "Computer Assisted Instruction that Works: Foreign \& Second Language Learning wih a New Technology". Presentor unknown at press time. 